\title{
PENERAPAN PENDEKATAN PEMBELAJARAN AKTIF INOVATIF KREATIF EFEKTIF DAN MENYENANGKAN (PAIKEM) PADA PEMBELAJARAN MATEMATIKA KELAS IV SD NEGERI O10 RAMBAH
}

\author{
Pariang Sonang Siregar ${ }^{1)}$, Lia Wardani ${ }^{2)}$, Rindi Genesa Hatika ${ }^{3)}$ \\ ${ }^{1,2)}$ STKIP Rokania \\ ${ }^{3)}$ Universitas Pasir Pengaraian \\ e-mail: sonang86@yahoo.co.id
}

\begin{abstract}
The purpose of this research is to improve the activity and learning outcomes of students on learning Mathemathics by appying PAIKEM learning approach in class IV SD Negeri 010 Rambah. This study is limited only to the applications of PAIKEM approach in improving the quality of Mahtematics learning and students learning outcomes. The research is a classroom Action Research (PTK) conducted with 4 cycles, each cycle is done by learning with PAIKEM approach. The results of the research can be concluded that the application of PAIKEM approach in learning Mathematics can improve student activity and student learning outcomes fourth grade SD Negeri 010 Rambah Rokan Hulu-Riau even semester 2016/2017. The results are as follows: 1) Improving the quality of student activity from cycle I by $50 \%$, cycle II by $80 \%$, cycle III by $92 \%$, and cycle IV by $98 \%$, there is an increase in student activity on the Mathematic to be highly qualified, 2) the learning outcomes of the first cycle of $90 \%$, the second cycle of $95 \%, 100 \%$ of the cycle III, and $100 \%$ of the cycle IV, which there is an increase in excellent learning outcomes, 3) Average value of the cycle I of 72.38, and second cycle is 83.00 , the third cycle is 90.50 , and the fourth cycle is 97.00 , the meaning is classically PAIKEM approath can increase the average of Mathematics students grade IV SD Negeri 0101 Rambah.
\end{abstract}

Keyword: PAIKEM approath, learning outcomes, student activity

\begin{abstract}
Abstrak: Tujuan dari penelitian ini adalah untuk meningkatkan aktivitas dan hasil belajar siswa pada pembelajaran Matematika dengan menerapkan pendekatan pembelajaran PAIKEM di Kelas IV SD Negeri 010 Rambah. Penelitian ini dibatasi hanya pada penerapan pendekatan PAIKEM dalam peningkatan mutu pembelajaran matematika dan hasil belajar siswa. Penelitian ini merupakan Penelitain Tindakan Kelas (PTK) yang dilaksanakan dengan 4 siklus, setiap siklus dilakukan pembelajaran dengan pendekatan PAIKEM. Hasil penelitiandapat disimpulkan bahwa penerapan pendekatan PAIKEM dalam pembelajaran Matematika dapat meningkatkan aktivitas siswa dan hasil belajar siswa kelas IV SD Negeri 010 Rambah Kabupaten Rokan Hulu-Riau semester genap tahun 2016/2017. Hasilnya sebagai berikut: 1) Peningkatan kualitas aktivitas siswa dari siklus I sebesar 50\%, siklus II sebesar $80 \%$, siklus III sebesar 92\%, dan siklus IV sebesar 98\%, terjadi peningkatan aktivitas siswa pada mata pelajaran Matematika menjadi sangat berkualitas, 2) Ketuntasan hasil belajar dari siklus I sebesar 90\%, siklus II sebesar 95\%, siklus III sebesar 100\%, dan siklus IV sebesar $100 \%$, dimana terjadi peningkatan hasil belajar yang sangat baik, 3) Ratarata nilai dari siklus I sebesar 72,38, dan siklus II sebesar 83,00, siklus III sebesar 90,50, dan siklus IV sebesar 97,00, maknanya secara klasikal pendekatan PAIKEM dapat meningkatkan rata-rata nilai Matematika siswa kelas IV SD Negeri 010 Rambah.
\end{abstract}

Kata Kunci: pendekatan PAIKEM, hasil belajar, aktivitas siswa 


\section{PENDAHULUAN}

Pendidikan merupakan lembaga sosial yang harus menyediakan sumber daya manusia (SDM) yang berkualitas dan mampu beradaptasi dengan perkembangan ilmu pengetahuaan dan teknologi. Berkaitan dengan hal tersebut diperlukan inovasi dalam proses belajar mengajar antara lain dalam pendekatan pembelajaran yang bertujuan untuk membantu perkembangan potensi dan kemampuan subyek didik sehingga bermanfaat bagi dirinya sendiri dan dan masyarakat, serta meningkatkan mutu pendidikan (Kussavita, 2007).

Proses belajar mengajar sangat menentukan peningkatan kualitas pendidikan. Perolehan belajar berupa nilai-nilai dan keterampilan tertentu terukur melalui proses dan hasil belajar. Sistem pembelajaran masa lalu dianggap tidak mampu lagi menopang tercapainya tujuan pendidikan secara menyeluruh. Oleh karena itu, upaya melakukan inovasi bidang pembelajaran selalu dikembangkan. Salah satu kemampuan yang harus dikembangkan dalam suatu penyelenggaraan pendidikan adalah kemampuan berhitung. Hal tersebut diterapkan melalui proses pembelajaran Matematika yang diajarkan di setiap jenjang pendidikan.

Matematika merupakan ilmu dasar yang sudah menjadi alat untuk mempelajari ilmu-ilmu yang lain. Oleh karena itu penguasaan terhadap matematika mutlak diperlukan dan konsep-konsep matematika harus dipahami dengan benar sejak dini. Hal ini karena konsep matematika merupakan suatu rangkaian sebab akibat. Suatu konsep disusun berdasarkan konsepkonsep sebelumnya, dan akan menjadi dasar bagi konsepkonsep selanjutnya, sehingga pemahaman yang salah terhadap suatu konsep, akan berakibat pada kesalahan pemahaman terhadap konsep selanjutnya. Atas dasar itulah penanaman konsep matematika mulai diajarkan pada siswa sekolah dasar (Cahya, 2006).

Matematika sering dianggap sebagai suatu pelajaran yang sulit, menakutkan dan menegangkan. Sutan (2003) mengatakan bahwa sebenarnya, ketakutan itu berawal dari pendekatan dalam mengajarkan Matematika yang terkesan kaku dan dogmatis. Siswa tidak diberi kesempatan untuk menemukan pengalaman Matematika dalam kehidupan sehari-hari

Kegiatan pembelajaran yang dilaksanakan guru juga masih bersifat teacher oriented, guru cenderung hanya memberikan atau memindahkan informasi sebanyak-banyaknya kepada siswa, sedangkan siswa hanya mendengar dan mencatat saja, membuat rangkuman materi, kemudian mengerjakan soal-soal pada LKS. Hal ini yang menyebabkan siswa menjadi pasif, tidak kreatif dan tidak inovatif dan sangat merugikan siswa karena siswa hanya memperoleh pengetahuan terbatas dari penjelasan guru dan materi dibuku, siswa tidak dapat mengembangkan potensi di dalam dirinya sehingga hasil belajar yang dicapai tidak optimal.

Sama halnya seperti pembelajaran matematika yang terjadi di SD Negeri 010 Rambah. Dimana pembelajaran matematika di sekolah ini masih dilaksanakan secara konvensional dan kurangnya rasa ingin tahu guru terkait inovasi pembelajaran yang menyenangkan.

Berdasarkan problematika tersebut, maka pendekatan PAIKEM merupakan pendekatan pembelajaran alternatif yang diyakini dapat mengatasi kendala tersebut serta penerapan model pembelajaran PAIKEM juga dapat meningkatkan hasil belajar siswa (Rahmawati,dkk, 2015). Model pembelajaran PAIKEM adalah model pembelajaran aktif, inovatif, kreatif, efektif, dan menyenangkan yang diberikan kepada siswa secara optimal untuk mencapai tujuan pembelajaran dalam suasana yang tidak membosankan siswa.

Menurut Slameto (2011),
PAIKEM mengandung makna
pembelajaran yang dirancang agar
mengaktifkan anak, mengembangkan
inovasi dan kreativitas sehingga efektif
namun tetap menyenangkan. Selain itu
juga, melihat karakteristik model
PAIKEM yang bersifat multi model,
multi metode dan multi media, sehingga
siswa tidak bosan karena guru tidak
hanya terpaku pada satu model, metode
dan media

2011), pembelajaran yang dirancang agar mengaktifkan anak, mengembangkan inovasi dan kreativitas sehingga efektif namun tetap menyenangkan. Selain itu juga, melihat karakteristik model PAIKEM yang bersifat multi model, multi metode dan multi media, sehingga siswa tidak bosan karena guru tidak dan media 
Penelitian ini dijadikan langkah awal untuk membuktikan bahwa dengan diterapkannya pendekatan pembelajaran PAIKEM dapat meningkatkan aktivitas dan hasil belajar siswa. Untuk itu peneliti mengadakan penelitian yang berjudul "Penerapan Pendekatan Pembelajaran Aktif Inovatif Kreatif Efektif Dan Menyenangkan (PAIKEM) Pada Pembelajaran Matematika Kelas IV di SD Negeri 010 Rambah".Adapun rumusan masalah dalam penelitian ini adalah: 1) Bagaimanakah kualitas aktivitas siswa dalam penerapan Pendekatan PAIKEM pada pembelajaran Matematika siswa kelas IV SD Negeri 010 Rambah? 2) Bagaimanakah hasil belajar siswa setelah penerapan pendekatan PAIKEM dalam pembelajaran Matematika siswa kelas IV SD Negeri 010 Rambah?

Tujuan dari penelitian ini adalah untuk meningkatkan aktivitas dan hasil belajar siswa pada pembelajaran Matematika dengan menerapkan pendekatan pembelajaran PAIKEM di Kelas IV SD Negeri 010 Rambah dan untuk meningkatkan mutu kualitas pembelajaran Matematika di SD Negeri 010 Rambah dengan adanya pembekalan pendekatan pembelajaran PAIKEM kepada guru-guru di sekolah tersebut.

Penelitian ini diharapkan dapat memberikan manfaat yaitu menumbuhkan minat dan bakat siswa dalam mempelajari matematika secara aktif, inovatif, kreatif, efektif dan menyenangkan sehingga dapat meningkatkan aktivitas dan hasil belajar, membekali guru dengan model-model pembelajaran aktif, dapat mengembangkan model pembelajaran aktif dengan kreativitas guru di sekolah sesuai dengan karakteristik siswa, menciptakan suasana belajar yang kondusif dan bebas dari tekanan dan intimidasi dalam usaha meyakinkan minat belajar siswa, dan mendorong terjadinya proses pembelajaran interaktif, kolaboratif, inkuiri dan discovery agar terbentuk budaya belajar yang bermakna (meaning full learning) pada siswa.

\section{Pembelajaran Aktif, Inovatif, Kreatif, Efektif, dan Menyenangkan}

PAIKEM merupakan singkatan dari Pembelajaran Aktif, Inovatif,
Kreatif, Efektif, dan Menyenangkan. Model pembelajaran ini menggambarkan keseluruhan proses belajar mengajar yang berlangsung menyenangkan dengan melibatkan peserta didik untuk berpartisipasi secara aktif selama proses pembelajaran. Untuk dapat mewujudkan pembelajaran yang aktif dan menyenangkan tersebut, tentu saja diperlukan ide-ide kreatif dan inovatif guru dalam memilih metode dan merancang strategi pembelajaran. Proses pembelajaran yang dilakukan dengan aktif dan menyenangkan diharapkan lebih efektif untuk mencapai tujuan pembelajaran yang telah ditetapkan sebelumnya. Pembelajaran yang aktif dan menyenangkan tidak efektif apabila tujuan belajar tidak tercapai dengan baik (Mulyatiningsih, 2010).

Dirjen Kependidikan (2010) juga menyatakan bahwa PAIKEM merupakan sebuah model pembelajaran yang memungkinkan siswa melakukan kegiatan (proses belajar) yang beragam untuk mengembangkan keterampilan, sikap dan pemahaman berbagai sumber dan alat bantu belajar supaya pembelajaran lebih menarik, menyenangkan dan efektif.

Karakteristik pembelajaran yang disebut PAIKEM menurut Slameto (2011) antara lain menggunakan multi metode dan multimedia, melibatkan semua indera, dengan praktik dan bekerja dalam tim, memanfaatkan lingkungan sebagai sumber belajar. Pembelajaran juga perlu melibatkan multi aspek yaitu logika, kinestika, estetika dan etika. Dengan kata lain pembelajaran perlu mengaktifkan siswa dan guru, membuat kreatif pembelajarnya, hasilnya efektif dan tentu saja semua berlangsung dengan menyenangkan.

Di Sekolah Dasar, pendekatan dalam pembelajaran yang dianggap relevan untuk menjawab tuntutan zaman adalah pendekatan pembelajaran, aktif, inovatif, kreatif, efektif, dan menyenangkan atau biasa disingkat PAIKEM. Dikatakan demikian karena pendekatan PAIKEM dapat mengakomodasi tuntutan perkembangan seluruh aspek dalam diri anak, baik dari kognitif, afektif maupun psikomotor.

PAIKEM merupakan sebuah tantangan bagi guru dan sekolah yang 
selama ini dianggap kurang dapat mengemas pembelajaran yang bermakna, berguna dan jauh dari tekanan. Guru profesional ditantang bagaimana mengelolah kelas dengan baik dan menciptakan suasana pembelajaran yang menyenangkan. Terwujud atau tidak PAIKEM dalam kelas diawali dari bagaimana guru dapat menata pembelajaran dengan baik. Harmonisasi pembelajaran dimulai dari kepiawaian guru sebagai pembangkit motivasi siswa, bagaimana memotivasi dan membangun serta menyelaraskan atau memperluas pengetahuan dasar yang dimiliki siswa, baik yang berkaitan dengan intlektualitas, personal, sosial, emosional dan kultural.

Pembelajaran

PAIKEM

merupakan sebuah model pembelajaran kontekstual yang melibatkan paling sedikit empat prinsip utama dalam proses pembelajarannya. Pertama, proses interaksi (siswa berinteraksi secara aktif dengan guru, rekan siswa, multi-media, referensi, lingkungan dsb). Kedua, proses komunikasi (siswa mengkomunikasikan pengalaman belajar mereka dengan guru dan rekan siswa lain melalui cerita, dialog atau melalui simulasi role-play). Ketiga, proses refleksi, (siswa memikirkan kembali tentang kebermaknaan apa yang mereka telah pelajari, dan apa yang mereka telah lakukan). Keempat, proses eksplorasi (siswa mengalami langsung dengan melibatkan semua indera mereka melalui pengamatan, percobaan, penyelidikan dan/atau wawancara).

Pelaksanaan PAIKEM harus memperhatikan bakat, minat dan modalitas belajar siswa, dan bukan semata potensi akademiknya, yaitu modalitas visual, auditorial dan kinestetik. Dengan modalitas visual dimaksudkan bahwa kekuatan belajar siswa terletak pada indera mata (membaca teks, grafik atau dengan melihat suatu peristiwa), kekuatan auditorial terletak pada indera pendengaran (mendengar dan menyimak penjelasan atau cerita), dan kekuatan kinestetik terletak pada perabaan (seperti menunjuk, menyentuh atau melakukan). Jadi, dengan memahami kecenderungan potensi siswa tersebut, maka seorang guru harus mampu merancang media, metoda/atau materi pembelajaran kontekstual yang relevan dengan kecenderungan potensi belajar siswa.

Penelitian relevan dilakukan pada tahun 2012, Habibah melakukan penelitian dengan judul "Penerapan Model PAIKEM untuk Meningkatkan Aktivitas dan Hasil Belajar Matematika Materi Pokok Bangun Datar pada Siswa Kelas V Madrasah Ibtidaiyah Nurul Hikmah Krandon Kota Tegal". Penelitian ini memperoleh kesimpulan bahwa penggunaan model PAIKEM dapat meningkatkan aktivitas siswa dan hasil belajar siswa. Hal ini terbukti bahwa persentase rata-rata aktivitas siswa pada siklus I mencapai $73,65 \%$ dan meningkat pada siklus II menjadi $77,34 \%$. Hasil belajar siswapun mengalami peningkatan pada setiap siklusny. Siklus I mendapatkan nilai rata-rata 66,65 dan meningkat pada siklus II sebesar 76,12.

Susanti, dkk pada tahun 2014 melakukan penelitian yang berjudul Penerapan Strategi Paikem Untuk Meningkatkan Aktivitas Dan Hasil Belajar Siswa. Dari penelitian ini didapati bahwa Berdasarkan hasil penelitian tindakan kelas yang dilakukan di kelas IV.C SD Negeri 1 Metro Pusat dapat disimpulkan bahwa penerapan strategi PAIKEM dapat meningkatkan aktivitas dan hasil belajar siswa. Hal ini terlihat dari nilai rata-rata aktivitas siklus I $(53,10)$ meningkat pada siklus II $(74,14)$. Rata-rata afektif siklus I $(65,51)$ meningkat pada siklus II $(74,95)$. Ratarata psikomotor siklus I $(54,37)$ meningkat pada siklus II $(74,16)$. Penilaian diri rata-rata siklus I $(72,64)$ meningkat pada siklus II $(80,35)$. Ratarata kognitif siklus I $(65,05)$ meningkat pada siklus II $(82,69)$.

Rahmawati, dkk pada tahun 2015 juga melakukan penelitian mengenai Penerapan Model Pembelajaran Paikem Untuk Meningkatkan Hasil Belajar IPA di Kelas V SD Negeri 3 Tompoh. Pada penelitian ini, Rahmawati, dkk mendapati bahwa dengan penerapan model pembelajaran PAIKEM dapat meningkatkan hasil belajar siswa.

Berdasarkan beberapa penelitian terdahulu dapat disimpulkan bahwa penelitian mengenai Penerapan Pendekatan Pembelajaran Aktif Inovatif Kreatif Efektif Dan Menyenangkan (PAIKEM) 
Pada Pembelajaran Matematika perlu dilakukan.

Mengingat bahwa matematika merupakan ilmu dasar yang sudah menjadi alat untuk mempelajari ilmuilmu yang lain. Oleh karena itu penguasaan terhadap matematika mutlak diperlukan dan konsep-konsep matematika harus dipahami dengan benar sejak dini. Apabila pembelajaran matematika hanya dilakukan dengan bersifat teacher oriented, Hal ini yang menyebabkan siswa menjadi pasif, tidak kreatif dan tidak inovatif dan sangat merugikan siswa karena siswa hanya memperoleh pengetahuan terbatas dari penjelasan guru dan materi dibuku, siswa tidak dapat mengembangkan potensi di dalam dirinya sehingga hasil belajar yang dicapai tidak optimal.

\section{METODE}

Jenis penelitian ini adalah Penelitian Tindakan Kelas (PTK) dengan menggunakan pendekatan PAIKEM yang dilaksanakan secara bersiklus terdiri dari 4 (empat) siklus. Adapun alur penelitian ini mengacu pada modifikasi diagram oleh Kemmis dan Mc. Tanggart dalam Depdiknas, (2003).

Indikator keberhasilan penelitian tindakan ini adalah bila daya serap siswa secara individu dari hasil belajar mencapai $65 \%$ dan ketuntasan hasil belajar siswa secara klasikal mencapai 85\% (Depdiknas, 2003).

Jenis data yang diperoleh dari penelitian ini adalah data kualitatif dan data kuantitatif. Data kualitatif yaitu data yang diperoleh dari siswa berupa data hasil observasi aktivitas dan data kuantitatif yaitu data yang diperoleh dari hasil belajar siswa.

\section{Teknik analisis data kuantitatif}

Teknik yang digunakan dalam menganalisis data dan menentukan persentase tingkat aktivitas dan ketuntasan belajar dengan menggunakan rumus Depdiknas (2003) sebagai berikut

a) Daya serap siswa secara individu

$$
\mathrm{DSI}=\frac{x}{y} \times 100 \%
$$

keterangan:

DSI $=$ Daya Serap Individu

$x=$ Skor yang diperoleh siswa $y=$ Skor maksimal soal

Siswa dikatakan tuntas individu jika daya serap siswa lebih dari atau sama dengan $65 \%$.

b) Ketuntasan hasil belajar Siswa secara klasikal

$$
\mathrm{KBK}=\frac{N}{S} x 100 \%
$$

Keterangan:

KBK = Ketuntasan Belajar Klasikal

$N=$ Jumlah siswa yang tuntas

$S=$ Jumlah siswa seluruhnya

Suatu kelas dikatakan tuntas belajar jika presentase ketuntasan belajar klasikal dari atau sama dengan $85 \%$ Siswa telah tuntas.

c) Indikator Kinerja

Indikator yang menunjukkan keberhasilan pembelajaran atau peningkatan hasil belajar siswa yaitu jika daya serap individu memperoleh nilai minimal $65 \%$ dari skor ideal dan ketuntasan klasikal minimal 85\% (Depdiknas, 2003).

\section{Teknik analisis data kualitatif}

Analisis data kualitatif dalam penelitian ini dilakukan selama dan setelah proses pengumpulan data yang diperoleh dari siswa berupa data hasil observasi aktivitas. Data hasil aktivitas siswa diperoleh dari lembar observasi, kemudian dianalisiss dalam bentuk persentase yang dihitung dengan menggunakan rumus :

$$
\begin{aligned}
& \text { Persentase Nilai Rata-rata } \\
& =\frac{\text { Jumlah skor perolehan }}{\text { Skor maksimal }} \times 100 \%
\end{aligned}
$$

Kategori penilaian

$90 \% \leq \mathrm{NR}<100 \%$ : Sangat Baik

$80 \% \leq \mathrm{NR}<90 \%$ : Baik

$70 \% \leq \mathrm{NR}<80 \%$ : Cukup

$60 \% \leq \mathrm{NR}<70 \%$ : Kurang

Penelitian ini dinyatakan berhasil jika hasil yang diperoleh telah berada dalam kategori baik atau sangat baik.

\section{HASIL DAN PEMBAHASAN}

Berdasarkan analisis data hasil penelitian siklus I, II, III, dan IV dapat dibandingkan untuk mengetahui tingkat keberhasilan peneliti sebagaimana dalam Tabel 1 berikut ini

Tabel 1. Rangkuman Perbandingan Hasil Penelitian 


\begin{tabular}{cccccc}
\hline \multirow{2}{*}{ No } & \multirow{2}{*}{ Aspek } & \multicolumn{4}{c}{ Hasil Siklus } \\
\cline { 3 - 6 } & & I & II & III & IV \\
\hline 1 & $\begin{array}{l}\text { Tingkat } \\
\text { Kualitas } \\
\text { Aktivitas } \\
\text { Siswa }\end{array}$ & $50 \%$ & $80 \%$ & $92 \%$ & $98 \%$ \\
\hline 2 & $\begin{array}{l}\text { Ketuntasa } \\
\text { n Hasil } \\
\text { Belajar }\end{array}$ & $90 \%$ & $95 \%$ & $100 \%$ & $100 \%$ \\
\hline 3 & $\begin{array}{l}\text { Rata-rata } \\
\text { Nilai }\end{array}$ & 72,38 & 83,00 & 90,50 & 97,00 \\
\hline
\end{tabular}

Tabel 1 menunjukkan bahwa dari 3 aspek yang diteliti, ternyata pada masing-masing aspek terjadi peningkatan yang teratur dan berkesinambungan (continous quality Improvement). Peningkatan masing-masing aspek dapat dilihat pada gambar berikut.

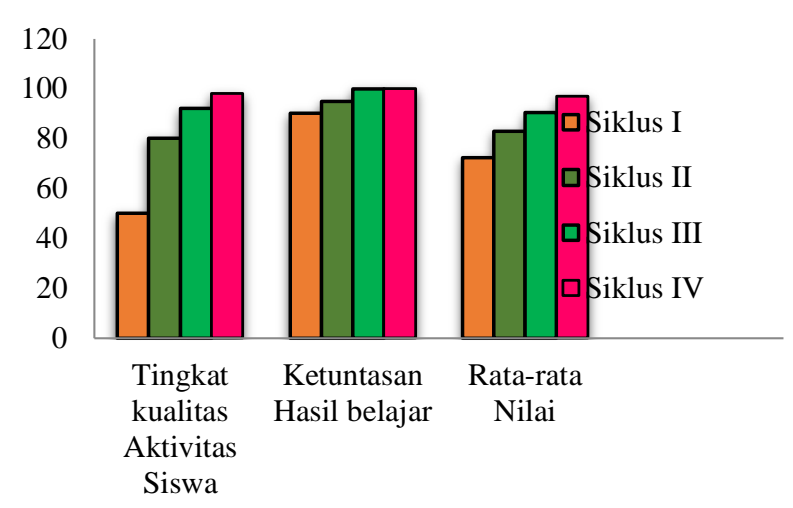

Gambar 1 Peningkatan Setiap Aspek Penelitian pada Siklus I, II, III, dan IV

Gambar 1 menunjukkan bahwa tingkat kualitas aktivitas siswa dalam pembelajaran Matematika melalui penerapan pendekatan PAIKEM mengalami peningkatan setiap siklus. Kemudian ketuntasan hasil belajar Matematika juga mengalami peningkatan setiap siklus. Selanjutnya rata-rata nilai setiap siklus mengalami peningkatan yang teratur dan berkesinambungan (continous quality Improvement).

Dalam proses pelaksanaan pembelajaran Matematika melalui penerapan pendekatan PAIKEM, dimana peneliti baru mengenal karakteristik siswa, ternyata siswa kelas IV sebagai subjek penelitian belum pernah merasakan pembelajaran dengan pendekatan PAIKEM. Pengaruh perbedaan penampilan peneliti dengan guru kelas IV jauh berbeda dari aspek penguasaan kelas, pendekatan pembelajaran yang digunakan, penggunaan media, gaya membelajarakan, dan aspek pedagogik lainnya.

Persentase kualitas aktivitas siswa setiap siklus mengalami peningkatan yang teratur dan berkesinambungan. Hal ini membuktikan bahwa para siswa sebagai subjek penelitian belum terbiasa menghadapi/menerima cara belajar yang baru dikenal siswa, sampai mereka menjadi aktif secara klasikal. Menurut Saefuddin dan Berdiati (2014:33) tujuan pendekatan PAIKEM ini adalah agar siswa mampu secara aktif memperoleh pengalaman belajar, mengembangkan kemampuan berpikir, menganalisis, mensintesis, menilai, dan menerapkannya dalam kehidupan sehari-hari.

Kualitas aktivitas siswa meningkat sangat baik dan berkesinambungan setelah penerapan pendekatan PAIKEM pada pembelajaran Matematika kelas IV SD Negeri 010 Rambah. Siswa berperan aktif baik secara individu maupun berkelompok, menyenangkan, bermain sambil belajar dan antusias dalam mengikuti pembelajaran Matematika selanjutnya

Bila penerapan pendekatan PAIKEM yang mempengaruhi hasil belajar dengan kualitas aktivitas siswa, maka hasil belajarpun akan meningkat. Hasil belajar siklus I sebesar 90\% siswa tuntas meningkat pada siklus II sebesar $95 \%$, meningkat lagi pada siklus III sebesar $100 \%$ dan dapat dipertahankan pada siklus IV sebesar $100 \%$. Secara kualitatif, penerapan pendekatan PAIKEM dan kualitas aktivitas siswa pada pembelajaran Matematika sangat berhubungan dan berpengaruh secara positif terhadap peningkatan hasil belajar siswa. Terbukti dari hasil pencapaian tiap siklus selalu mengalami peningkatan.

Jadi, penerapan pendekatan PAIKEM sangat berhasil dalam peningkatan hasil belajar Matematika siswa kelas IV SD Negeri 010 Rambah. Walapun ditemukan hanya seorang siswa yang berkompetensi lemah.

\section{SIMPULAN}

Berdasarkan hasil penelitian ditarik kesimpulan bahwa penerapan pendekatan PAIKEM dalam pembelajaran Matematika dapat 
meningkatkan aktivitas siswa dan hasil belajar siswa kelas IV SD Negeri 010 Rambah Kabupaten Rokan Hulu-Riau semester genap tahun 2016/2017.

Kesimpulan ini diperkuat dengan hasil sebagai berikut:

1. Peningkatan kualitas aktivitas siswa dari siklus I sebesar 50\%, siklus II $80 \%$, siklus III sebesar $92 \%$, dan siklus IV sebesar 98\%, terjadi peningkatan aktivitas siswa pada mata pelajaran Matematika menjadi sangat berkualitas.

2. Ketuntasan hasil belajar dari siklus I sebesar 90\%, siklus II sebesar 95\%, siklus III sebesar $100 \%$, dan siklus IV sebesar $100 \%$, dimana terjadi peningkatan hasil belajar yang sangat baik.

3. Rata-rata nilai dari siklus I sebesar 72,38, dan siklus II sebesar 83,00, siklus III sebesar 90,50, dan siklus IV sebesar 97,00, maknanya secara klasikal pendekatan PAIKEM dapat meningkatkan rata-rata nilai Matematika siswa kelas IV SD Negeri 010 Rambah.

\section{DAFTAR PUSTAKA}

Cahya P, Antonius. 2006. Pemahaman dan Penyajian Konsep Matematika Secara Benar dan Menarik. Jakarta: Depdiknas Dirjen Perguruan Tinggi Direktorat Ketenagaan.

Depdiknas. 2003. Penelitian Tindakan Kelas. Bahan Ajar Pembekalan Guru Bantu.

Dirjen Kependidikan . 2010. Pembelajaran Berasis PAIKEM. Direktorat Tenaga Kependidikan. Jakarta.

Habibah. 2012. Penerapan Model PAIKEM untuk Meningkatkan Aktivitas dan Hasil Belajar Matematika Materi Pokok Bangun Datar pada Siswa Kelas V Madrasah Ibtidaiyah Nurul Hikmah Krandon Kota Tegal. Skripsi. Tidak diterbitkan.

Kussavita, Riza., 2007. Aplikasi PAKEM (Pembelajaran Aktif Kreatif Efektif Menyenangkan)
Model Rancangan Alat Untuk Meningkatkan Prestasi Belajar Biologi Siswa Kelas Vii Smp N 1 Ambarawa Tahun Ajaran 20062007. Skripsi Mahasiswa. Universitas Sebelas Maret. Tidak diterbitkan.

Mulyatiningsih, E,. 2010. Pembelajaran Aktif, Kreatif, Inovatif, Efektif Dan Menyenangkan (PAIKEM). Diklat Peningkatan Kompetensi Pengawas Dalam Rangka Penjaminan Mutu Pendidikan. Jawa Barat.

Rahmawati. A, Mestawati. As, dan Lilies. 2015. Penerapan Model Pembelajaran Paikem Untuk Meningkatkan Hasil Belajar IPA Di Kelas V SDN 3 Tompoh. Jurnal Kreatif Tadulako Online Vol. 5 No. 10.

Rusman. 2013. Model-Model Pembelajaran. Jakarta: Rajawali Press.

Saefuddin, Asis \& Ika Berdiati. 2014. Pembelajaran Efektif. Bandung: Rosda.

Slameto. 2011. Model PAIKEM. Semarang: UNNES.

Sutan, Firmanawaty. 2003. Mahir Matematika Melalui Permainan. Jakarta: Puspa Swara.

Susanti, D., Ambarita, A., Astuti, N,. 2014. Penerapan Strategi Paikem Untuk Meningkatkan Aktivitas Dan Hasil Belajar Siswa. Jurnal FKIP Universitas Lampung. Tidak diterbitkan.

Tampubolon, Saur. 2014. Penelitian Tindakan Kelas. Jakarta: Erlangga. 